\title{
Abnormalities in Iron Metabolism in Multiple Sclerosis
}

\author{
Leslie S. Valberg, Peter R. Flanagan, Ann Kertesz and George C. Ebers
}

\begin{abstract}
High iron concentrations have been reported in the brains of multiple sclerosis victims. To determine if there are abnormalities in general iron metabolism indicative of iron overload in MS, measurements of transferrin saturation, serum ferritin and red cell ferritin in 31 female and 18 male patients were compared to the results in 49 age- and sex-matched healthy controls. Compared to controls, mean serum ferritin in MS was high, whereas transferrin saturation and red cell ferritin were similar. High values in one or more individual test results were observed in eleven MS patients. They were prevalent in patients who required bilateral assistance to walk or were confined to a chair, and appeared to be related to the severity of the disease. An investigation was made into the relationship of the high serum ferritin values in MS to the HLA-A $A_{3}$ histocompatibility antigen, a marker of the hemochromatosis gene which is prevalent in MS. A statistically significant interaction was not found between serum ferritin and the presence of HLA-A .
\end{abstract}

RÉSUMÉ: Anomalies du métabolisme du fer dans la sclérose en plaques Une concentration élevée en fer a été rapportée dans le cerveau de patients atteints de sclérose en plaques (SEP). Afin de déterminer s'il existe des anomalies du métabolisme général du fer indicatives d'une surcharge en fer dans la SEP, nous avons comparé les taux de saturation de la transferrine, de ferritine sérique et de ferritine des globules rouges chez 31 femmes et 18 hommes atteints de SEP et chez 49 contrôles sains appariés pour l'âge et le sexe. Le taux moyen de la ferritine sérique dans la SEP était élevé par rapport aux contrôles, alors que les taux de saturation de la transferrine et de ferritine des globules rouges étaient semblables. Des valeurs élevées pour un test particulier ont été observées chez onze des patients avec SEP, plus particulièrement chez les patients qui avaient besoin d'appui bilatéral pour marcher ou qui étaient en fauteuil roulant, et cette élévation semblait reliée à la sévérité de la maladie. Nous avons étudié la relation entre des valeurs élevées de ferritine sérique dans la SEP et l'antigène d'histocompatibilité HLA- $\mathrm{A}_{3}$, un marqueur du gène de l'hémochromatose ayant une fréquence élevée dans la SEP. Il n'existait pas d'interaction statistiquement significative entre la ferritine sérique et la présence du HLA-A

Can. J. Neurol. Sci. 1989; 16:184-186

White matter samples from brains of multiple sclerosis (MS) victims have significantly higher concentrations of iron, calcium and zinc, as compared to controls. ${ }^{1}$ Decreased signal intensity of T2-weighted MR images of the thalamus and putamen has been ascribed to iron deposition. ${ }^{2}$ Stainable iron deposits have been reported surrounding plaques in the brains of MS patients by one group, ${ }^{3}$ and not by another. ${ }^{4}$ The first objective of this study was to determine whether there were abnormalities in general iron metabolism indicative of iron overload in patients with MS. The second objective of this study was to determine whether or not abnormalities in general iron metabolism are linked to the HLA-A $\mathrm{A}_{3}$ histocompatibility antigen, a marker for the hemochromatosis igene. ${ }^{5}$ For example, in our hemochromatosis pedigrees, the prevalence of HLA-A ${ }_{3}, B_{7}$ and $\mathrm{B}_{14}$ in homozygotes is $62 \%, 57 \%$ and $22 \%$, respectively, compared to $25 \%, 22 \%$ and $8 \%$ in controls. Multiple sclerosis affects an ethnic population similar to hereditary hemochromatosis, and there is an increased prevalence of the HLA-A 3 antigen. 6

\section{MethodS}

\section{Patients with Multiple Sclerosis}

Blood samples were obtained from 49 patients (31 female and 18 male) who attended the MS clinic at University Hospital. None of the patients had clinical features of liver disease, infection, or other inflammatory conditions which are known to affect iron metabolism. The mean age was $43 \pm 11$ (standard deviation) years. The HLA-A 3 antigen was present in 39 percent of the patients. Four patients with HLA-A 3 and three patients without this allele had been taking iron supplements as part of a mineral-vitamin preparation.

\section{Controls}

The results obtained in patients for transferrin saturation and serum ferritin were compared to 49 age- and sex-matched controls (Group A) selected from the Nutrition Canada Survey.? The results for red cell ferritin were compared to a second control

From the Departments of Medicine and Clinical Neurological Sciences, The University of Western Ontario and University Hospital, London Received November 22, 1988. Accepted February 22, 1989

Reprint requests to: Dr. Leslie S. Valberg, Faculty of Medicine, Health Sciences Addition, University of Westem Ontario, London, Ontario, Canada $\mathrm{N} 6 \mathrm{~A}$ 5Cl 
group (B), matched for age and sex. ${ }^{8}$ The controls ranged in age from twenty to seventy-five years. None of them had symptoms or signs of illness. Individual hemoglobin concentrations were within the normal range for men and women.

\section{Hereditary Hemochromatosis}

The patients with MS were also matched for age and sex to 49 heterozygotes who were identified by HLA typing of pedigrees with hereditary hemochromatosis. ${ }^{9}$

\section{Iron Studies}

Serum iron and total iron binding capacity (TIBC) were measured using a diagnostic kit manufactured by Hoffman-La Roche Ltd., Montreal. Percent transferrin saturation was determined from the ratio of serum iron/TIBC. The range of normal values was $16-55 \%$. Serum ferritin was measured using a radioimmunoassay employing antibodies against human liver ferritin (Quant-immune Ferritin, IRMA, Biorad, Chemical Division, Richmond, California). Red cell ferritin was measured using the same commercial kit. ${ }^{8}$

\section{HLA Typing}

Typing for the A and B loci was performed by the complement-dependent cytotoxicity technique. ${ }^{10}$

\section{Statistical Analysis}

A one-tailed t-test (paired comparisons) was performed using a Hewlett Packard series 200 computer. A one-tailed test was used because we were testing whether the indices in iron metabolism were increased over controls. Frequency distribution of values for serum ferritin and red cell ferritin showed a skewed distribution, and were normalized by logarithmic transformation. Analysis of variance was performed with log-transformed data. Power analysis was done according to Armitage. ${ }^{11}$

\section{RESULTS}

\section{Iron Status of Patients with Multiple Sclerosis}

The mean transferrin saturation of patients with MS was similar to that of control Group A (Table 1). Mean serum ferritin concentration in the patients, $64 \mathrm{ng} / \mathrm{ml}$, was significantly

\begin{tabular}{|c|c|c|c|c|}
\hline Designation & $\begin{array}{c}\text { Number } \\
\text { of } \\
\text { Subjects }\end{array}$ & $\begin{array}{c}\text { Transferrin } \\
\text { Saturation } \\
\text { (percent) } \\
\text { Mean } \pm \text { SD }\end{array}$ & $\begin{array}{c}\text { Serum } \\
\text { Ferritin } \\
(\mathrm{ng} / \mathrm{ml}) \\
\text { Geometric } \\
\text { Mean } \\
\text { 5th \& 95th } \\
\text { Percentile }\end{array}$ & $\begin{array}{c}\text { Red } \\
\text { Blood Cell } \\
\text { Ferritin (ag/cell) } \\
\text { Geometric } \\
\text { Mean } \\
\text { 5th and 95th } \\
\text { Percentile }\end{array}$ \\
\hline Controls A & 49 & $24 \pm 8$ & $\begin{array}{c}37 \\
(6-206)\end{array}$ & \\
\hline B & 49 & - & - & $\begin{array}{c}10 \\
(5-21)\end{array}$ \\
\hline $\begin{array}{l}\text { Multiple } \\
\text { Sclerosis }\end{array}$ & 49 & $25 \pm 10$ & $\begin{array}{c}64^{a} \\
(6-323)\end{array}$ & $\begin{array}{c}13 \\
(4-56)\end{array}$ \\
\hline
\end{tabular}

$a=$ mean value of this group statistically significantly different from corresponding mean value of control group, $p<.01$, t-test paired comparisons. greater than the value of $37 \mathrm{ng} / \mathrm{ml}$ in control Group A, paired ttest, $\mathrm{p}<.01$. Red cell ferritin level in the patients, $13 \mathrm{ag} / \mathrm{cell}$, was not significantly different from control Group B, paired t-test, $p>0.01$. Five of the individual serum ferritin values, and nine of the individual red cell ferritin results in MS, exceeded the normal range of results for these tests (Table 2). When the tests were repeated two years later, serum ferritin remained elevated in five patients, and red cell ferritin was still high in six out of nine patients. Only one of these patients, $\mathrm{CP}$, was taking an over-the-counter iron supplement. The one patient, NG, with a marked fall in both serum ferritin and red cell ferritin, had developed hypothyroidism in the interim. High individual results for serum ferritin or red cell ferritin were about equally distributed between patients with HLA- $\mathrm{A}_{3}$ and without the HLA-A $\mathrm{A}_{3}$ antigen (Table 2).

\section{Comparison of Iron Status of MS Patients with Heterozygous Hemochromatosis}

The mean transferrin saturation, $25 \pm 10 \%$ (SD) in $49 \mathrm{MS}$ patients was significantly lower than the mean value of $34 \pm 14 \%$ in 49 heterozygotes, $\mathrm{p}<0.01$, paired t-test. Geometric mean serum ferritin in MS patients, $62 \mathrm{ng} / \mathrm{ml}$, was not statistically different from the mean value of 81 (8-375, 5th and 95th percentile respectively) $\mathrm{ng} / \mathrm{ml}$ in heterozygotes, $\mathrm{p}>0.10$, paired t-test. Mean red blood cell ferritin in MS patients, $13 \mathrm{ag} / \mathrm{cell}$, was statistically different from the mean value of 24 (5-71, 5th and 95 th percentile respectively) ag/cell in the heterozygotes, $\mathrm{p}<0.01$, paired $\mathrm{i}$-test.

\section{Relationship of Iron Status of MS Patients to the HLA-A Antigen}

Accepting the frequency of the hemochromatosis allele in the general population of $0.04-0.06$, and the probability of about 0.1912 that a chromosome carrying the $\mathrm{A}_{3}$ allele also carries the hemochromatosis gene, it can be estimated that about 4-5 of the nineteen $A_{3}$ positive MS patients were heterozygotes, compared to $2-3$ of the thirty $A_{3}$ negative MS patients. ${ }^{13}$

Application of a t-test for an interaction between HLA-A 3 antigen and the mean values for transferrin saturation, serum ferritin or red cell ferritin in MS patients with and without HLA-A $A_{3}$, revealed no statistically significant interaction. Assuming a standard deviation of 10 units, a two-sample comparison of 49 subjects in each group has $80 \%$ power $(\alpha=.05)$ of detecting a true difference in mean transferrin saturation of at least six units. " For red blood cell ferritin, similar calculations indicate that the two-group comparison has adequate power for detecting a true mean difference of 14 units. Thus the non-significant results for these two variables are based on sample sizes with sufficient statistical power for detecting moderately large differences.

\section{DisCUSSION}

Serum ferritin provides a good index of the size of body iron stores in healthy subjects. Serum ferritin levels may be increased disproportionate to the size of body iron reserves in the presence of infection or liver disease. The modest increase in serum ferritin in the individual MS patients, compared to controls, was not explained by these conditions. The high serum ferritin in MS patients could represent a non-specific increase due to inflammation associated with the disease process itself. ${ }^{14}$ 
Table 2: High Individual Results in Multiple Sclerosis Patients

\begin{tabular}{|c|c|c|c|c|c|c|c|c|c|c|c|c|}
\hline Initial & HLA-A $\mathbf{A}$ & Age/Sex & $\begin{array}{c}\text { Hemoglobin } \\
\text { g/L } \\
\mathbf{1 9 8 6}\end{array}$ & $\begin{array}{c}\text { Serum } \\
\text { Iron } \\
\text { umol/L } \\
1986\end{array}$ & $\begin{array}{c}\text { TIBC } \\
\mathrm{umol} / \mathrm{L} \\
1986\end{array}$ & \multicolumn{2}{|c|}{$\begin{array}{c}\text { Transferrin } \\
\text { Saturation } \\
(\%)\end{array}$} & \multicolumn{2}{|c|}{$\begin{array}{c}\text { Serum } \\
\text { Ferritin } \\
\text { ng/ml } \\
1986 \quad 1988\end{array}$} & \multicolumn{2}{|c|}{$\begin{array}{l}\text { Red Cell } \\
\text { Ferritin } \\
\text { ag/cell } \\
\end{array}$} & $\begin{array}{c}\text { Clinical } \\
\text { Condition }\end{array}$ \\
\hline HW & Yes & $32 \mathrm{~F}$ & 152 & 30 & 49 & 61 & 45 & 323 & 347 & 90 & 102 & deterioration \\
\hline MA & Yes & $33 \mathrm{~F}$ & 120 & 21 & 43 & 49 & 37 & 135 & 156 & 63 & 38 & stable \\
\hline $\mathbf{K M}$ & Yes & $37 \mathrm{~F}$ & 136 & 11 & 54 & 21 & 46 & 47 & 65 & 32 & 21 & deterioration \\
\hline $\mathbf{C P}$ & Yes & $58 \mathrm{~F}$ & 123 & 9 & 43 & 21 & 32 & 409 & 225 & 38 & 39 & stable \\
\hline JF & Yes & $33 \mathrm{M}$ & 156 & 17 & 46 & 37 & 32 & 129 & 97 & 36 & 23 & stable \\
\hline JB & No & $45 \mathrm{~F}$ & 137 & 17 & 48 & 35 & 30 & 250 & 270 & 56 & 41 & stable \\
\hline NG & No & $35 \mathrm{~F}$ & 142 & 18 & 58 & 30 & 12 & 153 & 9 & 202 & 7 & deterioration \\
\hline MS & No & $51 \mathrm{~F}$ & 153 & 22 & 57 & 39 & 26 & 54 & 37 & 39 & 32 & stable \\
\hline $\mathbf{R R}$ & No & $44 \mathrm{~F}$ & 133 & 15 & 47 & 31 & - & 106 & - & 27 & - & - \\
\hline NC & Yes & $68 \mathrm{M}$ & 140 & 16 & 50 & 33 & 18 & 596 & 534 & 22 & - & stable \\
\hline \multirow[t]{2}{*}{ TW } & No & $38 \mathrm{M}$ & 167 & 11 & 65 & 17 & 17 & 585 & 493 & 9 & 7 & deterioration \\
\hline & \multicolumn{2}{|c|}{ Normal Values } & $\begin{array}{l}\text { M } 135-160 \\
\text { F } 115-146\end{array}$ & $12-31$ & $45-73$ & \multicolumn{2}{|c|}{$16-55$} & $\begin{array}{l}\text { M } 1 \\
\text { F } 1\end{array}$ & $\begin{array}{l}8-350 \\
8-200\end{array}$ & \multicolumn{2}{|c|}{$4-25$} & \\
\hline
\end{tabular}

High values were evident, however, in patients whose condition was stable, as well as in those where it was deteriorating.

Nine of the eleven MS patients with abnormalities in iron metabolism required bilateral assistance to walk or were restricted to wheelchair or chair. Normally, skeletal muscles serve as an important storage site for body iron. The total amount of iron stored here is about the same as that found in the liver and bone marrow respectively. ${ }^{14}$ It is possible that muscle atrophy in the MS patients led to a shift of iron from muscle to the liver or reticuloendothelial system, and this contributed to the high serum ferritin values.

None of the MS patients with the HLA-A $\mathrm{A}_{3}$ marker selected for this study had increases in transferrin saturation, serum ferritin and red cell ferritin that are typical of homozygous hemochromatosis. No homozygotes have been recognized on clinical grounds in the 1,700 MS patients we have encountered. Partial biochemical expression of the hemochromatosis gene, characterized by a modest increase in mean transferrin saturation and serum ferritin, was evident in the heterozygotes selected for this study. No increase in transferrin saturation was apparent, however, in the MS patients. Although serum ferritin was high in MS patients, the increase in serum ferritin was apparent in the presence of, and in the absence of, the HLA-A histocompatibility antigen (Table 2).

While there was no apparent systematic association between high serum ferritin values and the HLA-A $\mathrm{A}_{3}$ histocompatibility antigen, it is still possible that abnormalities in some individuals reflect the co-association of hemochromatosis and MS with HLA-A $A_{3}$. To explore this possibility will require a method for the direct detection of the hemochromatosis gene. At present, this is not feasible.

\section{ACKNOWLEDGEMENTS}

We are grateful to John Ninness and Jim Haist for technical assistance in performing the ferritin assays, and to Allan Donner for statisti- cal advice. This study was supported by a grant from the Medical Research Council.

\section{REFERENCES}

1. Craelius W, Jacobs RM, Lee Jones AO. Mineral composition of brains of normal and multiple sclerosis victims. Proc Soc Exp Biol and Med 1980; 160: 327-329.

2. Drayer B, Burger P, Hurwitz B, et al. MRI of brain iron. AJR 1987; 149: 357-363.

3. Craelius W, Migdal MW, Luessenhop CP, et al. Iron deposits surrounding multiple sclerosis plaques. Arch Pathol Lab Med 1982; 106: 397-399.

4. Walton JC, Kaufmann JCE. Iron deposits and multiple sclerosis. Arch Pathol Lab Med 1984; 108: 755-756.

5. Simon M, Bourel M, Genetet B, et al. Idiopathic hemochromatosis. Demonstration of recessive transmission and early detection by family HLA typing. N Engl J Med 1977; 297: 1017-1021.

6. Ebers GC. Immunogenetics and CSF studies in multiple sclerosis. In: VandenBark AA, Raus JCM, eds. Immunoregulatory Processes in Experimental Allergic Encephalomyelitis and Multiple Sclerosis. Elsevier Science Publishers BV 1984; 233256.

7. Valberg LS, Sorbie J, Ludwig J, et al. Serum ferritin and the iron status of Canadians. CMAJ 1976; 114: 417-421.

8. Cruikshank MK, Ninness J, Curtis A, et al. Usefulness of erythrocyte ferritin analysis in hereditary hemochromatosis. CMAJ 1987; 136: 1259-1264.

9. Borwein ST, Ghent CN, Flanagan PR, et al. Genetic and phenotypic expression in hemochromatosis in Canadians. Clin Invest Med 1983; 6: 171-179.

10. Mittal KK, Mickey MR, Singal DP, et al. Serotyping for homotransplantation. 18. Refinement of microdroplet lymphocyte cytotoxicity test. Transplantation 1968; 6: 913-927.

11. Armitage P. Statistical methods for medical research. John Wiley, $1983 ; 186$.

12. Simon $M$, Brissot $P$. The genetics of hemochromatosis. J Hepatol 1988; 6: 116-124.

13. Yaouang J, Simon M. HLA alleles, hemochromatosis allele, and serum ferritin in hemodialysis patients. Nephron 1988; 50: 259260.

14. Bothwell TH, Charleton RW, Cook JD, et al. Iron metabolism in man. Oxford: Blackwell Scientific Publications 1979; 92. 